\title{
Academic Entrepreneurship vs. Changing Governance and Institutional Management Structures at European Universities
}

\author{
MAREK KWIEK \\ Center for Public Policy, \\ Poznan University, Poland
}

\begin{abstract}
This article discusses academic entrepreneurship in the context of ongoing changes in university management and governance in European universities. The comparative perspective is provided by the European Union (EU) research project 'European Universities for Entrepreneurship: Their Role in the Europe of Knowledge' (EUEREK) comprising seven European countries, and it draws heavily from ideas and research results of Burton Clark, Michael Shattock and Gareth Williams. It views transformations in university governance and management in the context of the recent emphasis by the European Commission (EC) on the vital role of changes in institutional governance and its 'modernisation agenda for universities'. The article presents a general discussion of the EC's prioritisation of areas of transformation of European universities in which governance structures figure prominently, discusses the role of risk-taking at entrepreneurial institutions and shows the role of risk management. It also discusses the clash of old academic and new managerial values at entrepreneurial universities and the traditional academic idea of collegiality. Finally, conclusions are drawn regarding the future of public institutions in Europe.
\end{abstract}

\section{Introduction}

This article discusses academic entrepreneurship in the context of ongoing changes in university management and governance in European universities. The comparative perspective of the paper is provided by the European Union (EU) research project 'European Universities for Entrepreneurship: Their Role in the Europe of Knowledge' (EUEREK) (6th Framework Programme of the EU, 2004-2007), comprising seven European countries, and it draws heavily from ideas and research results of Burton Clark, Michael Shattock and Gareth Williams. It is intended to view transformations in university governance and management in the context of the recent emphasis by the European Commission (EC) on the vital role of changes in institutional governance in its 'modernisation agenda for universities' (EC, 2006a).

The first section ('University Governance and the European Commission on the Roles of Universities') provides a general discussion of the EC's prioritisation of areas of transformation for European universities, in which governance structures figure prominently. The next section then discusses the role of (academic, reputational, and financial) risk-taking at entrepreneurial institutions, which is viewed as their core feature, and it shows the role of risk management in both public and private institutions. The section following that discusses the unavoidable clash of old academic and new managerial values at entrepreneurial universities and the institutional ways to deal with it. Tensions between the university centre and basic academic units are then discussed 
and the context is provided by the traditional academic idea of collegiality. A move away from (but not getting rid of) collegiality in university management at public entrepreneurial universities studied is emphasised. Different governance and management structures are reported in small private institutions - they can be simplified to the extreme and the phenomenon is related to their fundamental financial uncertainty, studied as an example of the survival culture developed in the last fifteen years, especially in European transition economies. The pivotal role of strategic committees and strong management groups is shown. The section entitled 'Entrepreneurship, Centralisation, and Decentralisation' discusses entrepreneurship as a phenomenon appearing at both (not too) centralised and (not too) decentralised institutions and, in more detail, 'earned income' policies found at the core of transformations of the University of Warwick from the 1980s onwards and the crucial role of strategic committees in changes in resource allocation models and in resulting changes in universities' priority research areas. The penultimate section discusses the spread of academic entrepreneurship across institutions and highlights the difference between most entrepreneurial university units in western Europe (research in natural sciences and technology in public universities) and most EU transition countries (teaching-related entrepreneurship in social sciences and economics in both public and private institutions). Finally, tentative conclusions are drawn.

\section{University Governance and the European Commission on the Roles of Universities}

In recent discussions about the future of public universities in Europe, the issue of their governance and management structures figures prominently. The overall picture on reading, in particular, recent EU documents, reports, working papers and communications is that the relationship between government and universities is in need of profound change. The two most recent documents, 'Mobilising the Brainpower of Europe' (EC, 2005a) and 'Delivering on the Modernisation Agenda for Universities' (EC, 2006a) (and a number of accompanying documents; see EC, 2003a, b, 2005b, c, 2006b), make clear that radical transformations of university governance are expected by the EC to make possible their full contribution to the 'more jobs/more growth' component of the Lisbon Strategy. Universities are urged to consider fundamentally new arrangements (new 'contracts') with societies, and governments are urged to consider establishing new partnerships with universities, with a shift from state control to accountability to society (EC, 2005a, p. 9). As explained clearly in an EU issue paper on university governance:

Universities operate in a fast changing context. ... Consequently, universities are becoming more complex and difficult to manage, internally and in relation with the state. Coordinated change is required both in systems regulation and in institutional governance in order to mobilise the enormous potential of knowledge and energy of European universities to adapt to new missions. (EC, 2006b, p. 1)

Changes in governance are thus needed: according to new university/government contracts envisaged by the EU, universities will be responsible and accountable for their programmes, staff and resources, while the state will be responsible for the 'strategic orientation' of the system as a whole - through a framework of general rules, policy objectives, funding mechanisms and incentives (EC, 2006a, p. 5). Or as the policy is laid down expressis verbis, 'less ex ante checks and greater ex post accountability of universities', with full autonomy as a pre-condition for universities (EC, 2005a, p. 7). In general terms, institutional governance issues seem more crucial than any other factor discussed in connection with the current role of universities in knowledge-based economies, including public funding for them:

Institutional governance is of the utmost importance in a competitive and global context,

because it is the main factor in reinforcing leadership and accountability in European

Universities. It may be considered that other factors, namely public financing of universities and research activities, are important for the future of European universities, but the choices made by universities concerning governing bodies and decision making processes are vital in their consolidation. (EC, 2005c, p. 38, emphasis mine)

In the above context, out of the three dimensions of university governance (governing bodies, executive bodies and external quality assurance bodies; see EC, 2005c, p. 39), the present article will 
focus on the first two, and especially on what Burton Clark called 'a strengthened steering core', the first of five elements of the entrepreneurial university, the university's 'administrative backbone' stretching from central university bodies to its major faculties, departments, and institutes. (In his classical formulation in Creating Entrepreneurial Universities, the remaining four elements are an expanded developmental periphery, a diversified funding base, a stimulated academic heartland, and an integrated academic culture; Clark, 1998, p. 5; see also Clark, 2004a, b).

A more general issue (reaching beyond university governance and management) raised frequently by the EC in the last few years is the following: are the transformations facing European universities radical - and if so, why? As a communication on 'Investing Efficiently in Education and Training: an imperative for Europe' argues, the challenge in education and training is likely to be bigger than envisaged in Lisbon in 2000: 'simply maintaining the status quo or changing slowly would clearly be hugely inadequate in the face of such a massive challenge' (EC, 2002, p. 11).

Consequently, the EU today needs 'a healthy and flourishing university world'; it needs more 'excellence' in its universities. At present, though, just as the situation of research is 'worrying', the situation of universities is 'bad' because they are not 'globally competitive ... even though they produce high quality scientific publications' (EC, 2003b, p. 2). European universities generally have less to offer than their main competitors, the communication goes on to argue. Following the criticism of the first communications about the common European research area regarding the mission of universities, the EC wanted to be as careful as possible about the role of universities, stating, inter alia, that universities still 'hold the key to the knowledge economy and society' (EC, 2003b, p. 5); universities are also 'at the heart of the Europe of Knowledge' (EC, 2003b, p. 4). At the same time, the stakes are very high and universities in the form in which they are functioning now are not acceptable in the Commission's view. Its largely economic perspective is quite clear here and the idea is conveyed in many passages of the communication in fairly strong formulations.

European universities have 'enormous potential' but this potential 'is not fully harnessed and put to work effectively to underpin Europe's drive for more growth and more jobs'. Research is no longer an isolated activity and emphasis in research is shifting from individual researchers to 'teams and global networks' (EC, 2006a, p. 3). Therefore universities need autonomy and accountability; and full institutional autonomy to society at large requires new internal governance systems, based on strategic priorities, professional management of human resources, investment and administrative procedures (EC, 2006a, p. 5). From a larger perspective, as the title of another EU communication recently put it, the implementation of the Lisbon Strategy requires 'fostering entrepreneurial mindsets through education and learning' (EC, 2006c), from primary to secondary to higher education. With reference to the latter, the document promotes the commercialisation of ideas and development of new technologies by students and researchers (EC, 2006c, p. 9).

Consequently, universities face an imperative need to 'adapt and adjust' to a series of profound changes Europe has been undergoing (EC, 2003b, p. 6). They must rise to a number of challenges. They can only release their potential by undergoing the radical changes needed to make the European system a genuine world reference' (EC, 2003b, p. 11). They have to increase and diversify their income in the face of the worsening underfunding. The great golden age of universities' Ivory Tower ideal (not mentioned in the communication by name, though) is over:

[A]fter remaining a comparatively isolated universe for a long period, both in relation to society and to the rest of the world, with funding guaranteed and a status protected by respect for their autonomy, European universities have gone through the second half of the 20th century without really calling into question the role or the nature of what they should be contributing to society. (EC, 2003b, p. 22, emphases mine)

The fundamental question about European universities today is the following: 'Can the European universities, as they are and are organised now, hope in the future to retain their place, in society and in the world?' (EC, 2003b, p. 22, emphasis in original; see also Kwiek, 2005, 2006). It is a purely rhetorical question in the context of the whole communication on the 'role of universities in the Europe of Knowledge': the universities in Europe - as they are and as they are organised today will not be able to retain their place. Restructuring is necessary, and a much wider idea of European social, economic and political integration applied to the higher education sector, expressed in the ideals of a common European higher education area, comes in handy. Let us recall the goal of the common research area in another formulation (from 'Strategy for a Real Research Policy in 
Europe') to see how far away it is from traditional views on the social role of the university: the university's goal is the creation of an area for research where scientific resources are used 'to create jobs and increase Europe's competitiveness' (EC, 2000, p. 1). Universities today are increasingly responsible to their stakeholders; university training does not only affect those who benefit directly from it, the inefficient use of resources by public universities affects society at large. Thus the objective, the EC goes on to argue, is to 'maximise the social return of the investment' or 'to optimise the social return on the investment represented by the studies it [society] pays for' (EC, 2003b, p. 14).

Finally, the EC, in its recent paper entitled 'Mobilising the Brainpower of Europe', enumerates several 'bottlenecks' to university reforms: uniformity in programmes and methods; insularity from the industry; over-regulation by the state; under-funding; and dependency on state funding (EC, 2005a, pp. 3-4). The university modernisation agenda includes the three aspects: attractiveness of European higher education systems, their funding, and their governance and institutional management issues. Somewhat surprisingly, EC documents on the future of the university generally do not refer to discussions of the last decade about New Public Management (NPM) in Anglo-Saxon countries, the 'reinventing government' movement in the United States, and the phenomenon of managerialism. Despite some similarities with the EU agenda on universities with NPM (improving performance by emphasising customer service, decentralisation, market mechanisms, cross-functional collaboration and accountability for results [Page, 2005, pp. 713-714]), the parallels are not drawn in EC documents. Also the general theme of academic entrepreneurship is not being directly linked to NPM; it is rather viewed as a revenue-side solution to financial austerity problems of public universities. In this article, we are focusing on the third aspect raised by the EC - governance and management issues in a particular context of academic entrepreneurship (and we are leaving aside possible parallels between transformations in governance and management between NPM and the entrepreneurship theme in universities, especially because among the countries studied, only in one - the United Kingdom - has NPM developed).

\section{Academic Entrepreneurship and Risk Management}

In the context of recent EU emphasis on the necessary changes in governance structures in the European universities, let us focus on the meso-level of particular institutions: which changes can be observed, and which trends they may be implicating. In general terms, according to Gareth Williams, there can be identified three basic university management structures and styles: collegial, bureaucratic and entrepreneurial (Williams, 2004, pp. 84-92). Collegial management means that the academic staff or their representatives take all important decisions through a process of consensual decision-making - until a broad agreement about the way forward is reached. The processes of consultation are inevitably time-consuming, and decision-making processes are slow. In hard times, though, it is almost impossible to reach agreement about where cuts should be made - except for a situation of 'misery for all'. Bureaucratic management, in turn, means a form of organisation in which everyone in a management hierarchy has freedom to act within prescribed limits - decisions are taken quickly but a small number of individuals at the apex make final decisions and there is a we/they feeling of alienation in an institution. Entrepreneurial forms of management are most likely to be found when the institution needs to generate income or to enhance its reputation in a variety of different ways - in order to prosper or to survive. Universities or departments which are able to keep any income they earn are most likely to behave entrepreneurially. According to Williams, 'the key to entrepreneurial management styles is an understanding and management of risk. Managers who take risks and are successful are rewarded. Failure and passivity are penalized' (Williams, 2004, pp. 86-87).

The role of strong core administrators - accompanied by strong strategic committees - is emphasised in many EUEREK (and other) case studies of European universities. Managing structures and decision-making processes at a small private university (the University of Buckingham in the UK) are substantially different from those at bigger institutions (such as Warwick and Nottingham Universities in the UK or Twente University in the Netherlands; see Schutte, 1999; Mallon, 2004; Middlehurst, 2004; Lazzeretti \& Tavoletti, 2005). For example, the 
three schools at Buckingham are each treated as a separate business division, and each is responsible for maximising its financial return (derived largely from teaching). The decision process at Buckingham is quick and involves five people who meet regularly every week (EUEREK, 2006, pp. 14-15 - case study: University of Buckingham).

Academic entrepreneurialism involves risk-taking (Shattock, 2003; Williams, 2007, p. 19); in most EUEREK case studies, institutions have to deal with a high level of risks on a daily basis; in private institutions, the major risk studied is a financial one, related to student number figures (and student fees). But, as Michael Shattock explains, in universities 'risks may be academic or reputational as well as financial' (Shattock, 2005, p. 19). According to the Polish case study of a medium-sized, vocationally oriented private institution (WSHIG - Academy of Hotel Management in Poznan):

WSHIG has been operating under constant risk in recent years. The major risk has been financial - will the income from student fees cover the expenditures, especially including debt installments to the banks. WSHIG has been investing heavily in its infrastructure. As other private institutions, only from its own sources, with no state subsidies. WSHIG's rector was doing wonders to be able to pay back the bank loans in time (also using his private assets). The second risk has been student enrolments. (EUEREK, 2006, p. 12, case study: WSHIG - Poland)

There are also other forms of risks involved in EUEREK institutions: the competition in the areas of studies (for instance, public institutions suddenly opening the same study programmes or modifying the existing ones in the same city - and running them without charging student fees); and unpredictable and changing state regulations, for instance related to the faculty minimum requirements; and the risk of losing academic prestige (institutional reputation). The role of risk management in entrepreneurial universities seems crucial: what is stressed is monitoring performance at individual levels by heads of departments (and at the same time by members of the strategic management team); risk management focuses also on outside grants. Structured risk management, with respect to both finances and reputation, is often used as well (see EUEREK, 2006, p. 23 - case study: London School of Hygiene and Tropical Medicine [LSHTM]).

\section{A Clash of Academic and Managerial Values?}

In the UK, changes with respect to funding in several universities seem to point in the direction not only of steps taken by British institutions but also of those (at least considered to be) taken in major continental higher education systems. As Shattock noted, 'the UK public universities were already operating in a marketised system and generating substantial non-core income in 1994, while they have mostly grown their non-core income considerably, the growth has done no more than to keep pace with the growth of core income. All the other countries, starting later, have begun to move rapidly in the direction the UK followed before 1994' (Shattock, 2007, pp. 15-16: introduction to EUEREK revised report; see also Shattock, 2000, 2002). The changes in funding and in governance and management often go hand in hand, and the UK is a good example. Nottingham's management structure is similar to that of Warwick: a strong management board is accompanied by strategic committees. Committees deal with specific issues, while day-to-day management operations are done by the management board; the role of the university council is reduced but academic consultations are performed through committees. There is a balance between bottom-up initiatives and top-down strategic guidance. The role of strategic committees at Nottingham University is explained as follows:

In 1995 a new streamlined committee and management structure was introduced. Day to day management issues at the University are the responsibility of the Management Board, which meets weekly. This group also initiates strategy. It currently comprises the ViceChancellor, the six Pro-Vice Chancellors, the Chief Financial Officer and the Registrar. ... The Management Board is a sub-committee of the Strategy and Planning Committee, a committee of the University Council, which is legally responsible for all the strategic decisions of the University. (EUEREK, 2006, p. 3: case study: University of Nottingham) 
Management structures at Manchester University (outside the EUEREK focus) are more traditional but seem equally effective, especially as regards the strong position of the vice-chancellor and his management team. Its governance structures include the Board of Governors, to which the president and the vice-chancellor (one person) reports; the senate is the principal academic authority and its responsibilities are limited to academic issues - it is chaired by the president and the vice-chancellor; there is also general assembly (a rare body at the entrepreneurial universities studied), with limited powers; finally, the registrar and the secretary (one person) serves as a secretary to the board, the senate, and the general assembly - and at the same time serves as the head of administration of the university, responsible to the president and vice-chancellor for providing administrative support. Most importantly, the president and vice-chancellor is the CEO of the university and he/she is responsible for the establishment and the composition of his/her management team. In more general terms, although the senate and the general assembly do exist, their powers are limited and power is located in the university's core management team headed by a vice-chancellor. Interestingly, heads of schools (deans of faculties) are members of the management team as vice-presidents - which ensures that there are few hierarchical layers between academic activities in schools (departments) and senior management of the university (see Arnold et al, 2006, pp. 74-75).

In general terms, the strengthened steering core means the operationalised reconciliation of 'new managerial values' and 'older academic values'. If these values are not reconciled, institutions feel tensions which require top management's (sometimes considerable) attention. The idea (operationalised - e.g. at Manchester University) that heads of schools and deans are members of a senior management team at the central level brings academic units and their representatives closer to the central management. The tensions can be smaller as it is the job of deans and heads of schools to keep explaining actions taken at the senior administrative level (in Polish public universities, deans of faculties - but not heads of departments, smaller academic units - form a body of all deans at a central level, cooperating closely on a weekly basis with the rectorate, the university's chief management body). As in the example below, from Nottingham, it is not easy to reconcile academic and managerial values:

However, managing university staff is a notoriously difficult exercise, especially when at least some aspects of marketing and entrepreneurial activities seem to conflict with deeply held academic values. Effective power in a university is intrinsically and inevitably deeply embedded in academic staff of the institution, because only they have the expertise to make it work. The pro-vice-chancellors at Nottingham devote a considerable amount of time in proselytising within the institution. (EUEREK, 2006, pp. 8-9: case study: University of Nottingham)

The administration of entrepreneurial institutions studied managed to fuse new managerial values with traditional academic values; in no successful cases of academic entrepreneurship reported in the EUEREK project, the attempts to eradicate the traditional academic values and to replace them with managerial ones succeeded.[1] The reason seems to be that it is the traditional disciplinerelated departments where both major teaching and research are still being done. It is also expected to be so in the future in public non-profit institutions.

\section{Academic Entrepreneurship and Collegiality}

The available case studies of entrepreneurial universities in Europe show three methods to minimise tensions between the centre and the base academic units, the third being used alongside the first and the second as well. The first method is pursuing a flat management structure, eliminating intermediate units (faculties), to minimise barriers between the centre and the basic units (departments) - examples are the University of Warwick and the University of Joensuu, Finland (both analysed by Burton Clark) or the vast majority of Polish private institutions (See Kwiek, 2008a, b, c). The case study of WSHIG in Poznan provides a good example; there is the rector and his small team of collaborators, the strategic management team - and departments, without the level of faculties. In the flat management structure there are no deans; the departments and research centres have direct contact with the centre, which consists of the vice-chancellor's 
office and a number of central interlocked (through some overlapping participation) committees. A perfect example of a successful flat management structure in Europe is provided by Warwick.

The second method to minimise tensions is keeping three-level arrangements, increasing authority and responsibility of existing multiple levels (the centre-faculties-departments); the examples are Twente University (the Netherlands) and the Chalmers University of Technology (Sweden), also both analysed by Clark. The method is having the traditional basic structure - a small central office headed by the rector, president or vice-chancellor; faculties headed by deans; and departments chaired by heads. The difference from traditional collegial structures is stronger personal authority in line positions and, at the same time, greater collegial authority in academic committees. This is thus the combination of stronger individual authority of rectors, deans and heads of departments, combined with stronger collegial authority of committees and higher professionalisation of central administration. The new bodies comprising the two increased authorities are 'university management groups' or 'university management teams'. There are dangers that too much power given to the departments may lead to the gradual disintegration of the university as a whole (the university may become increasingly merely an aggregate of its entrepreneurial units and individuals, as the former Twente University rector stresses).

The third method to minimise tensions between the centre and the base academic units is the professionalisation of administration all along the line, and particularly at the centre, as exhibited at entrepreneurial universities in Europe which have flat structures as well as those which keep the traditional three-level arrangements. Multiple non-academic tasks are increasingly being performed by well-paid experts and specialists, rather than amateurs recruited from among former or current academics; these units include especially finances, student affairs, alumni and fundraising affairs. More and more previously unknown administrative posts are being created; in the Polish case, they include new administrative units for EU structural funds, units for EU research programmes, units for technology transfer, university foundations to promote the university brand and so on (as the EUEREK Poznan University case study shows [EUEREK, 2006]).

Most case studies available, both from Europe and from the USA, indicate that the issue of academic autonomy and academic collegiality in managing entrepreneurial universities cannot be forgotten in most successful cases. There are many cases of excessive centralisation and examples of getting rid of (sometimes already remnants of) academic collegiality. The best examples of this trend are found in Australia and New Zealand (the Monash case study by Simon Marginson, 2000; The Enterprise University case studies edited by Marginson \& Considine, 2000; case studies reported in Currie \& Newson, 1998, Gallagher, 2000, Sporn, 2001; Deem, 2001; Currie, 2002). Certainly the general trend in the overwhelming majority of public and private sector institutions, not merely entrepreneurial ones, seems to be away from powerful senates and general assemblies and towards strengthened rectors'/vice-chancellors' offices at the central level. In many countries (among transition countries, especially several western Balkan countries should be mentioned: Bosnia and Herzegovina, Macedonia, and Kosovo - the single most visible exception being Slovenia), there is a substantial - and paralysing, and dangerous to the healthy existence of academic institutions devolution of authority down to faculties. Public universities in these countries, especially the largest and most prestigious 'national' universities such as Sarajevo University, Skopje University and Pristhina University, are most often loose federations of (almost fully) autonomous faculties. Consequently, the introduction of new university structures through new laws on higher education is very difficult in these countries, especially as long as faculties remain separate legal entities. The idea of 'integrated university' - a strong centre and weaker faculties and departments, legal personality accorded only to the university as a whole, as well as financial integration represented by the university having a single bank account and faculties no longer having their own separate accounts - has been promoted in the western Balkans for several years now, but with very limited success, as new laws have generally not been adopted. The major implications of not having legal and financial integration at public universities in these countries include the practical inability to charge university overheads on faculties' revenues, resulting in limited university-level reforms or activities; the practical inability to introduce the Bologna Process basic requirements (ECTS, i.e. European Credit Transfer System, Diplomma Supplement, two-tier structure of studies); and, finally, the inability to produce a coherent, and appealing, vision of the future of top public institutions (for CEE countries, see Kwiek, 2004, 2008a, b, c). 
While the above universities are considering advantages and disadvantages of legal and financial integration of the university as an institution, the governance structures at Twente University, an example of an entrepreneurial and decentralised university, are 'flat': 'Within this new organisational structure a decision-making process was introduced in which the deans and the scientific directors form the university management team (UMT), together with the Executive Board. While the Executive Board is ultimately responsible, the UMT sets out the strategic direction of the university. The result of all the changes is a 'flat' organisation, which can respond directly and collectively to developments in the social-cultural, political or economic environment of the university (Arnold et al, 2006, pp. 38-39).

In small private institutions, both governance and management structures and procedures may be simplified to the extreme. These simplified structures are often reported in European transition countries in new private institutions which have sometimes appeared out of nowhere, with no international investments or public subsidies involved, and which in their first years of operation had been constantly in danger of a financial collapse (WSHIG in Poznan being a perfect example). The culture of financial survival, as reported within the EUEREK project in Spain, Russia, Moldova and Poland, has been very strong in these institutions. The consequences for management styles and managerial practices are significant: decisions are taken by one to five people; there is almost no spirit of collegiality; and all major (and sometimes even most minor) decisions are actually taken by rectors/owners/founders of these institutions - who are often the same persons. These simplified management structures seem to be possible only in relatively small private institutions which have no major research ambitions and which are relatively non-competitive workplaces for the staff. There are virtually no research funds available to these institutions (either from private or public sources), and consequently most academic decisions are relatively non-controversial and teaching-related decisions. The decisions in the vast majority of cases pertain to funding - for example, the division of research funds available between faculties and departments, or the crosssubsidisation of particular study programmes. In the private sector, unsuccessful programmes are merged or closed rather than cross-subsidised by thosethat are more financially successful. As in the Polish case of WSHIG, all key decisions are taken by the rector, there is no senate, the management team is small and very effective; all senior administrative staff, including three vicerectors, have been working for WSHIG for a decade or more and the key for its success is the loyalty of its staff (EUEREK, 2006, p. 15: case study: WSHIG).

What do the agents of change/transformation do - those leaders located in the strengthened managerial core of entrepreneurial universities? They (as Clark, 1998, pp. 137-138, explains) seek other patrons in funding; work to diversify income and enlarge the pool of discretionary money available to an institution; seek out new infrastructure units (academic and administrative alike) that reach across old university boundaries, and reach the outside world of firms and companies. They are necessary for the task of cross-subsidising fields and degree levels, taxing richer programmes and aiding those less fortunate (top-slicing the profits). So they seek to subsidise new activities and try to enhance old valuable programmes. The steering core is responsible for keeping the right balance between rich and poor departments. Another example of successful managing by a senior management group (called there a 'university management group' [UMG]) comes from Strathclyde University: it is 'the key management body that undertakes the formulation of major policy and oversees the operational management of the university on behalf of the Court and Senate. ... The Group meets fortnightly and works to a tight, fully prepared agenda. It has its own Secretariat to prepare the business for its discussion. Decisions taken by UMG are reported to Senate and Court on a regular basis' (Sir John Arbuthnott, quoted in Clark, 2004a, p. 25).

\section{Entrepreneurship, Centralisation, and Decentralisation}

It is important to stress the role of non-monetary dimensions of entepreneurialism, such as academic prestige or institutional reputation. An entrepreneurial university will, as Williams puts it, 'reward departments and individual members of staff according to their success in bringing resources or reputation into the institution. Activities that are unable to make a net surplus, in either income or institutional reputation, are discontinued' (Williams, 2004, pp. 86-87). Again in general terms, as the case studies of entrepreneurial universities show (also previous Russian cases 
discussed in the Shattock's [2004a] volume on entrepreneurialism of Russian universities), there is always some degree of collegiality and some bureaucracy - but the shift in managerial styles reported in Europe in the last twenty years is away from both collegiality and bureaucracy, and towards entrepreneurial styles of management. In practice, the shift means, for instance, that the vice-chancellor has acquired increased managerial powers and that he or she is now supported by a small but very powerful strategic management group that determines the strategic directions and ensures links between the vice-chancellor's office and the university staff. Universities introduce clear resource allocation models (RAMs), supervised by these teams, which allocate the income of the university among the university units and determine what percentage of the commercial income shall be treated as indirect costs and what are the 'top-slicing' procedures. Usually, a formula basis is used - but its exact components are constantly under review (and under discussion between the centre and the academic units).

Resource allocation models used in entrepreneurial universities studied have strategic implications for the nature of an institution: institutions become more centralised or more decentralised. Through the allocation of resources, some strategic decisions are followed to the detriment of others, as Jarzabkowski stresses (Jarzabkowski, 2002, p. 5). Hard choices have to be made, and they are often being made by using allocation models. The example of strategic decisions is the route followed by Warwick University between 1992 and 1998: 'Warwick has consistently pursued goal-oriented actions related to research excellence, income-generation, capital expansion and growth of the Science Faculty' (Jarzabkowski, 2002, p. 12).

Effective entrepreneurial universities are neither extremely centralised nor extremely decentralised; they are administratively strong at the top, the middle, and the bottom. The decentralised entrepreneurial university is certainly Warwick University; the centralised one, on the other hand, is Twente University in the Netherlands (both being objects of Clark's and others' case studies in the last ten years). They introduce professionalised clusters of change-oriented administrators at all levels - development officers, technology-transfer experts, finance officials, sophisticated staff managers - to help raise income and establish better internal cost control. Entrepreneurial universities develop a 'new bureaucracy' (as Clark calls it) as a key component of their (entrepreneurial) character. This new bureaucracy is especially visible in public universities in new EU countries, from Slovenia to Poland to Romania: they have needed more specialised administrative staff in the last ten years to make use of both EU research and structural funds.

It is important to avoid the conception of overpersonalised leadership, though: the European case studies of entrepreneurial universities clearly indicate that strong and devoted leadership is not enough to introduce, or sustain for the future, structural changes. The CEO kind of management, the authoritarian figure, in most cases does not endure. As Clark phrased it, based on his 14 global case studies, 'enterprising universities ... are characterized by collegial entrepreneurialism' (Clark, 2004a, p. 85). Also, none of the case studies of successful entrepreneurial universities in Europe reported the crucial role of charismatic leaders in the long run; in the medium run, they were able to start transformations. Consequently, the case studies available show the crucial role of strong 'university management teams' (or bodies with similar names and functions) in Europe - who interact with both governing bodies above and the academic bodies (departments, schools, and so on) below where the real work, and real transformations, are done. University management teams, or senior management teams, report to governance boards or boards of management. The pivotal role of these strong teams was stressed at, for example, the LSHTM and Strathclyde University in the UK, Twente University in the Netherlands, and WSHIG in Poland. New governance structures are described at the LSHTM, studied within the EUEREK project, as follows: 'The Board is required to be accountable to HEFCE [Higher Education Funding Council for England] as the governing body of the institution. Below there is a School Senate, a reformed body from a previous Academic Board on which all professors and readers were ex-officio members. The new Senate has 30 rather than the previous 90 members and has a wider participation from the staff (EUEREK, 2006, p. 22: case study: LSHTM).

Similar transformations in management structures are reported in numerous case studies of most successful institutions, academically, reputationally, and financially. Senior management teams are reported to be the decision-making bodies, responsible to governing bodies. The list of senior management team members is getting longer and may include, apart from vice-chancellor, 
pro-vice-chancellors, registrar and so on, research finance officers or research contracts officers. The following extract is a reflection on recent changes in governance at LSHTM:

Key changes to the management of the School were introduced in the late 1980s by a Dean ... who operated very much in a chief executive mode. He introduced the concept of a Senior Management Team (SMT), which has continued to be the decision-making body in the School (subject of course to the constitutional powers of the governing body). This now consists of the Director, deputy Director, the three heads of departments, the Director of the Teaching Programme and the Secretary and Registrar.... There is no doubt that the operation of the SMT, meeting weekly, lies at the heart of the successful management of the School. It conforms precisely to Clark's 'strengthened steering core' mechanism. (EUEREK, 2006, p. 20: case study: LSHTM)

As reported at Twente University, the decentralisation of the university and its entrepreneurialisation may reach its limits. As the former rector, Frans van Vught, highlights, an entrepreneurial university can become too entrepreneurial and too decentralised: the discretionary funding base can become substantive enough to allow the base units to follow their own course of action, without reference to the overall course of the institution. The base units can become selfsupporting groups that can act as individual entrepreneurs. Thus the entrepreneurial university should not become a 'university of entrepreneurs' (Clark, 2004a, p. 40).

The opposite direction - centralisation - was taken in making the University of Warwick a model of European academic entrepreneurship: the core is strong and centralised, and departments are basic units; there are no intermediate levels of deans or faculties. It is at Warwick that an idea and then consistent university policy - of the 'earned income' was formulated. An 'earned income group' in the 1980s became the instrument for entrepreneurialism, working on adding new sources of university revenues in the times of Margaret Thatcher's budget cuts (in short: companies should not give us money, we want to earn it; as Michael Shattock, quoted by Clark, put it: 'we had to find ways to generate funding from other sources; we did not see why people or companies would simply give us money so we decided to earn it' [Clark, 1998, p. 16]). The 'earned income policy' worked in the following way: the group was 'top-slicing' various incomes generated by various units, it expected a 'profit' from other units, and professional managers were hired to run various units. Accounts were closely studied for current performance against set targets; successful performances were praised. Several accounts (e.g. student residences) were expected to merely break even, but all the others had to operate under the dictate of earning income, according to overall 'earned income' university policy. The university committees were allocating sums to departments and were controlling faculty positions. The innovative 'flat management structure' introduced at Warwick has been very successful but it would not be possible to go forward without a (somehow complementary) system of powerful centralised committees.

Managing resource allocation in entrepreneurial universities studied is most often operationalised through committees: small and medium-sized (see also Sharma, 2004, pp. 112-113). How to achieve strong management? There are several ways described on the basis of case studies of entrepreneurial institutions. One method is to strengthen the role of vice-chancellor or principal; other ways include the creation of deputy vice-chancellors as full-time, permanent or fixed-term appointments. Additionally, directors of finance and human resources are now usually key members of the senior management team. The key corporate functions of planning, estates, finances, human resources, learning and information and corporate services are likely to be represented alongside the academic functions of teaching and learning, research and enterprise (see Middlehurst, 2004, pp. 272-273).

\section{Academic Entrepreneurship Spread across Institutions}

The most frequent mistake made in attempts to transform universities is for a management team to proceed on its own, without involving faculty and their departments from the outset, Clark (2004b) claims. Some departments can and will move faster than others in understanding the benefits of entrepreneurial actions, their own as well as those located elsewhere in the university. Most social science and humanities departments may underestimate the role of new peripheral supporting units, and criticise their running costs (e.g. technology transfer or contracts and grants 
offices). Generally, science and technology departments lead the change, enabled by sources of support directly available to them and prepared by their experience in administrating costly projects, laboratories, and equipment.

Departments positioned to raise income should be encouraged to do so by other departments, and thereby to contribute to the welfare of the entire university as well as their own. It is then a second-order problem to work out who decides what share of the enhanced resources each gets. It is here that the whole complicated issue of 'top-slicing' and 'cross-subsidising' appears which may cause substantial tensions within an organisation. Both Clark's case studies and other European case studies of entrepreneurial universities show that there is uneven spread of entrepreneurialism within an institution, with various speeds of change, most often depending on external, especially funding, opportunities. The University of Warwick provides an excellent example of financial management with respect to the earned income - a crucial component of the third stream of university income, perhaps most valuable to the university from the standpoint of its entrepreneurial character. The university, administered through the system of central committees, has a strong capacity to 'top-slice' the profits and to 'cross-subsidize' (for a variety of reasons) less financially successful departments, which makes it possible to help those departments which cannot easily raise their money or to support new academic or administrative undertakings. As Shattock, quoted in and Clark, explains the Warwick case: 'It is accepted that it is to the university's advantage that those departments that can generate income should support those departments that are simply unable to do so [the cross-subsidy].' And as Clark comments, 'The centre then has to have the power and legitimacy to say 'it is accepted' because this is the way we build the university as a whole' (Clark, 1998, p. 24; see also Shattock, 2004b, pp. 225-235, on the earned income policy).

While in western Europe and the United States, apparently the most enterprising parts of the traditional academia (Clark's 'academic heartland') are in the science and technology areas, in most transition countries the case studies available confirm that the most entrepreneurially minded units, departments, institutions, as well as academics are in the 'soft' areas of studies and research: economics, law, business, management, marketing, sociology, and political sciences. These are the areas in which the largest part of the private sector operates, and in which the public sector runs its most enterprising study programmes for fee-paying students (all Polish, Russian, and Moldavian EUEREK case studies confirm this concentration of teaching-related entrepreneurship in soft areas of social and economic studies). Also the availability of research grants, including international research grants, in these areas seems considerable.

As is evident from EUEREK case studies, in transition economies 'soft' disciplines, including especially economics, law, business and social sciences, are much more easily fundable nationally and internationally, and consequently they are much more agents of entrepreneurial changes in academic institutions.

\section{Tentative Conclusions}

EUEREK (and other) case studies confirm the pivotal role of changing governance at most entrepreneurially oriented universities in Europe. They confirm what the EC expressed in 2006: 'European universities have enormous potential, much of which unfortunately goes untapped because of various rigidities and hindrances. Freeing up the substantial reservoir of knowledge, talent, and energy requires immediate, in-depth and coordinated change: from the way in which systems are regulated and managed, to the ways in which universities are governed' (EC, 2006d, p. 1). It seems clear that the general line of EC thinking is that current governance and management structures at most European universities are obsolete and do not provide an adequate basis to reach the goals envisaged by the EC within the Lisbon Strategy. It comes as no surprise that what provides the perspective for looking at higher education is the relevance of education/training to the Lisbon goal' rather than relevance to anything more general (EC, 2002, p. 6). The issue of university funding is closely linked to that of governance: as the communication entitled 'Mobilising the Brainpower of Europe' remarks, 'investing more in the current system could be perceived as unproductive, or even counter-productive' (EC, 2005a, p. 8; on how to close the funding gap in European higher education, see Mora, 2001). European systems need profound changes which have been spotted at the most entrepreneurial (mostly UK) universities: more 
accountability; financing linked to academic performance (e.g. a balance between core, competitive, and performance-based funding; more competition-based funding in research; and more output-related funding in education); and the wider use of market (or quasi-market) mechanisms (see also Temple, 2006). These changes require new governance and management systems, often already individually (and in cases remaining in isolation from one another) tested in selected European institutions. The determination of the EC to implement the 'modernisation agenda' for universities can be confirmed by emphatic references to other sectors where reforms have been seen, with various degrees of success, as unavoidable: the steel industry and agriculture. The EU now faces 'the imperative to modernise its 'knowledge industry' and in particular its universities' (EC, 2005a, p. 10). Case studies of selected European institutions show that the university modernisation as envisaged by the EC has already been in progress across Europe and, at the same time, that ongoing transformations in university governance and management open anew discussions about the clash of old academic and new managerial values, the role of collegiality and the new prioritisation of teaching and research areas at (increasingly) entrepreneurial institutions.

\section{Acknowledgements}

EUEREK case studies: 27 universities from Poland, Moldova, Russia, Spain, the United Kingdom, Finland and Sweden, for the project 'European Universities for Entrepreneurship - Their Role in the Europe of Knowledge', 6th Framework Programme of the European Union (2004-2007), coordinated by the Institute of Education, University of London (Michael Shattock, Gareth Williams, Paul Temple), publicly available from http://www.euerek.info. Theoretical results have been produced in EUEREK (2007) and Shattock (2008). The author would like to express his gratitude to the whole EUEREK research team; responsibility for all limitations of the present article rests with him only, though.

\section{Notes}

[1] A different story is provided by 'corporate universities', private for-profit institutions, active largely in very selected areas of studies and research, including computing, accounting, business law, and so on. Somewhat surprisingly, this sector has been fully neglected in major case studies of entrepreneurial universities available on a European scale; they were, however, studied separately, for example within the ongoing 'Program on Research of Private Higher Education' (PROPHE) at the State University of New York (SUNY) at Albany.

\section{References}

Arnold, E., Deuten, J. \& Zaman, R. (2006) Four Case Studies in University Modernisation: KU Leuven, Twente, Manchester and Loughborough. Enschede: Technopolis.

Clark, B. (1998) Creating Entrepreneurial Universities: organizational pathways of transformation. New York: Pergamon Press.

Clark, B. (2004a) Sustaining Change in Universities: continuities in case studies and concepts. Maidenhead: Open University Press.

Clark, B. (2004b) Delineating the Character of the Entrepreneurial University, Higher Education Policy, 17, 355-370.

Currie, J. (2002) Australian Universities as Enterprise Universities: transformed players on a global stage, in proceedings of the conference 'Globalisation: what issues are at stake for universities?' http:/ / www.bi.ulaval.ca/Globalisation-Universities/pages/actes/

Currie, J. \& Newson, J. (Eds) (1998) Universities and Globalization: critical perspectives. Thousand Oaks: Sage.

Deem, R. (2001) Globalisation, New Managerialism, Academic Capitalism and Entrepreneurialism in Universities: is the local dimension still important? Comparative Education, 37(1), 7-20.

http: / / dx.doi.org/10.1080/03050060020020408

EUEREK (2006) Case Studies of 27 European Universities. http:/ / www.euerek.info 
EUEREK (2007) European Universities for Entrepreneurship: their role in the Europe of knowledge (EUEREK). Revised report (Deliverable 12). Submitted to the European Commission, January 2007.

European Commission (EC) (2000) Strategy for a Real Research Policy in Europe. Brussels. IP/ 00/ 52.

European Commission (EC) (2002) Investing Efficiently in Education and Training: an imperative for Europe. Brussels, COM(2002) 779 final.

European Commission (EC) (2003a) 'Education and Training 2010': the success of the Lisbon Strategy hinges on urgent reforms. Brussels, $\operatorname{COM}(2003) 685$ final.

European Commission (EC) (2003b) The Role of Universities in the Europe of Knowledge. Brussels, $\operatorname{COM}(2003) 58$.

European Commission (EC) (2005a) Mobilising the Brainpower of Europe: enabling universities to make their full contribution to the Lisbon Strategy. Brussels, COM(2005) 152 final.

European Commission (EC) (2005b) European Higher Education in a Worldwide Perspective. Commission Staff Working Paper. Brussels, SEC(2005) 518.

European Commission (EC) (2005c) European Universities: enhancing Europe's research base. Report by the Forum on University-based Research. Brussels: DG Research.

European Commission (EC) (2006a) Delivering on the Modernisation Agenda for Universities: education, research and innovation. Brussels, $\operatorname{COM}(2006) 208$ final.

European Commission (EC) (2006b) Cluster 'Modernisation of Higher Education'. Issue paper on Governance. Brussels, Doc. MHE 7.

European Commission (EC) (2006c) Implementing the Community Lisbon Programme: fostering entrepreneurial mindsets through education and learning. Brussels, COM(2006) 33 final.

European Commission (EC) (2006d) Europe Needs Modernised Universities, Says European Commission. IP/06/592, Brussels, 10 May.

Gallagher, M. (2000) The Emergence of Entrepreneurial Public Universities in Australia. Canberra: Department of Education.

Jarzabkowski, P. (2002) Centralised or Decentralised? Strategic Implications of Resource Allocation Models, Higher Education Quarterly, 56(1), 5-32. http: / / dx.doi.org/10.1111/1468-2273.00200

Kwiek, M. (2004) The Emergent European Educational Policies under Scrutiny: the Bologna Process from a central European perspective, European Educational Research Journal, 3(4), 759-776. http: / / dx.doi.org/10.2304/ eerj.2004.3.4.3b

Kwiek, M. (2005) The University and the State in a Global Age: renegotiating the traditional social contract? European Educational Research Journal, 4(4), 324-342. http: / / dx.doi.org/ 10.2304/ eerj.2005.4.4.1

Kwiek, M. (2006) The University and the State: a study into global transformations. Frankfurt am Main: Peter Lang.

Kwiek, M. (2008a) On Accessibility and Equity, Market Forces and Entrepreneurship: developments in higher education in central and eastern Europe, Higher Education Management and Policy, 20(1), 89-110.

Kwiek, M. (2008b) Entrepreneurialism and Private Universities, in Michael Shattock (Ed.) Entrepreneurialism in Universities and the Knowledge Economy. Diversification and Organisational Change in European Higher Education, 78-97. Maidenhead: Open University Press.

Kwiek, M. (2008c) The Two Decades of Privatization in Polish Higher Education: cost-sharing, equity, and access. Die hochschule, 2, 94-112.

Lazzeretti, L. \& Tavoletti, E. (2005) Higher Education Excellence and Local Economic Development: the case of the Entrepreneurial University of Twente, European Planning Studies, 13(3), 475-493. http: / / dx.doi.org/ 10.1080/09654310500089779

Mallon, W. (2004) Disjointed Governance in University Centers and Institutes, New Directions for Higher Education, 127, 61-74. http:/ / dx.doi.org/ DOI: 10.1002/he.156

Marginson, S. (2000) Monash: remaking the university. Sydney: Allen \& Unwin.

Marginson, S. \& Consodine, M. (2000) The Enterprise University. Power, Governance and Reinvention in Australia. Cambridge: Cambridge University Press.

Middlehurst, R. (2004) Changing Internal Governance: a discussion of leadership roles and management structures in UK universities. Higher Education Quarterly, 58(4), 258-279. http: / / dx.doi.org/10.1111/j.1468-2273.2004.00273.x

Mora, J. (2001) Governance and Management in the New University, Tertiary Education and Management, 7(2). 95-110. http:/ / dx.doi.org/10.1023/A:1011338016085 
Page, S. (2005) What's New about the New Public Management? Administrative change in the human services, Public Administration Review, 65(6), 713-727. http:/ / dx.doi.org/10.1111/j.1540-6210.2005.00500.x

Schutte, F. (1999) The University-Industry Relations of an Entrepreneurial University: the case of the University of Twente, Higher Education in Europe, 24(1). http: / / dx.doi.org/ 10.1080 / 0379772990240105

Sharma, R. (2004) Performance-based Funding in the Entrepreneurial North American and Australian Universities, Journal of Higher Education Policy and Management, 26(1), 109-118. http: / / dx.doi.org/10.1080/1360080042000182564

Shattock, M. (2000) Strategic Management in European Universities in an Age of Increasing Institutional SelfReliance, Tertiary Education and Management, 6(2), 93-104. http: / dx.doi.org/10.1023 / A:1009665119955

Shattock, M. (2002) Re-balancing Modern Concepts of University Governance, Higher Education Quarterly, 56(3), 235-244. http: / dx.doi.org/10.1111/1468-2273.00215

Shattock, M. (2003) Managing Successful Universities. Buckingham: Society for Research into Higher Education (SRHE).

Shattock, M. (Ed.) (2004a) Entrepreneurialism and the Transformation of Russian Universities. Paris: UNESCO/International Institute for Educational Planning (IIEP).

Shattock, M. (2004b) Generating Non-State Income in European Universities, in M. Shattock (Ed.) Entrepreneurialism and the Transformation of Russian Universities. Paris: UNESCO/International Institute for Educational Planning (IIEP).

Shattock, M. (2005) European Universities for Entrepreneurship: their role in the Europe of knowledge. The theoretical context, Higher Education Management and Policy, 17(3), 1-16.

Shattock, M. (2007) Research and Technology/Knowledge Transfer, in EUEREK (European Universities for Entrepreneurship: their role in the Europe of knowledge), revised report (Deliverable 12). Submitted to the European Commission, January 2007.

Shattock, M. (2008) Entrepreneurialism in Universities and the Knowledge Economy. Diversification and Organisational Change in European Higher Education. Maidenhead: Open University Press.

Sporn, B. (2001) Building Adaptive Universities: emerging organisational forms based on experiences of European and US Universities, Tertiary Education and Management, 7(2), 121-134. http:/ / dx.doi.org/10.1023/ A:1011346201972

Temple, P. (2006) Intervention in a Higher Education Market: a case study, Higher Education Quarterly, 60(3), 257-269. http: / / dx.doi.org/10.1111/j.1468-2273.2006.00320.x

Williams, G. (2004) The Changing Political Economy of Higher Education, in M. Shattock (Ed.) Entrepreneurialism and the Transformation of Russian Universities. Paris: UNESCO/International Institute for Educational Planning (IIEP).

Williams, G. (2007) Finance and Entrepreneurial Activity in Higher Education in a Knowledge Society, in EUEREK (European Universities for Entrepreneurship: their role in the Europe of knowledge), revised report (Deliverable 12). Submitted to the European Commission, January 2007.

MAREK KWIEK is the founder and director of the Center for Public Policy, Poznan University, Poland, and professor in its Department of Philosophy. His research interests include globalisation and higher education, European educational policies, welfare state reforms, and transformations of the academic profession, as well as philosophy of education and intellectual history. Currently, he is a Fulbright 'New Century Scholar' 2007-2008 ('Higher Education in the 21st Century'). Correspondence: Professor Marek Kwiek, Center for Public Policy, Poznan University, Ul. Szamarzewskiego 89, PL-60 569 Poznan, Poland (kwiekm@amu.edu.pl). 